\title{
A magyar alpesi sízők és hódeszkázók egészségkárosodásainak összehasonlító statisztikai elemzése
}

\author{
Felkai Péter dr. ${ }^{1}$ - Lengyel Ingrid ${ }^{1}$ - Szokoly Miklós dr. ${ }^{2}$ - Forgó Gábor dr. ${ }^{1}$ \\ ${ }^{1}$ SOS Hungary Orvosi Szolgálat, Budapest \\ ${ }^{2}$ Fővárosi Önkormányzat Péterfy Sándor Utcai Kórház és Rendelőintézet, Budapest
}

\begin{abstract}
Bevezetés és célkitüzés: A magyarok téli sportolási szokásai nagymértékben különböznek a külföldiekétől. Közleményünkben megvizsgáltuk a magyar síelők és hódeszkások sérüléseinek jellemzőit. Módszer: 222, síeléssel és hódeszkázással összefüggő egészségkárosodás került statisztikai elemzésre. Eredmények: A havas sporttal összefüggő egészségkárosodások közül $201(90,5 \%)$ sísérülés, $19(8,6 \%)$ snowboardos sérülés és $2(0,9 \%)$ pályán kívüli síeléssel összefüggő sérülés történt. A sísérülések $55,8 \%$-a az alsó végtagon történt, a térdsérülés $36,8 \%$ volt. A snowboardos sérüléseknél a csukló sérülése 31,6\% volt. A 222 sérült közül 29 beteget (13\%) kellett repatriálni. Köpetkeztetés: A felmérésben szereplő egészségkárosodások mindegyike télisport-sérülés volt. Megállapítható, hogy a téli sportot űző magyarok sérülési arányai és az egyes testrészek sérülései nagyjából korrelálnak a nemzetközi irodalomban közölt epidemiológiai adatokkal. A síelók és a hódeszkások csuklósérülései azonban a magyar sportolóknál az irodalmi adatokhoz képest jelentősen emelkedett számot mutattak, míg a fejsérülések aránya kisebb volt, mint a nemzetközi szakirodalomban említett érték. Orv. Hetil., 2017, 158(16), 618-624.
\end{abstract}

Kulcsszavak: térdsérülés, síelés, snowboard, hazaszállítás, sportsérülés

\section{Epidemiological data of Hungarian skiers' and snowboarders' medical problems}

Introduction and aim: There are no high mountains or any advantageous circumstances for winter sports in Hungary, yet within the 10 million population there are about half a million people (the exact number is 550,000 ) who tend to go for skiing or snowboarding abroad. Authors compared the injury statistical data with results described in the international literature in order to develop conclusions about the differences in the injury patterns and frequency between the Hungarian ones' and those found in countries with plenty of winter sport possibilities. Method: Authors analysed the winter sport injury cases of an insurance company. All the injury happened abroad and the assistance provider of the insurance company has managed the patient treatment and repatriation. Three winter seasons (12 months) data was analysed from the point of view of injuries frequency at different body parts and areas. Due to the fact that only limited information was available a simple statistical method was applied. Results: Of 222 cases 90.5\% were ski-related injury and $8.6 \%$ were snowboard injury. As for the skiers, the upper limb injuries accounted for $21.9 \%$, the truncal region for $24.4 \%$ and the lower limb for $55.8 \%$. Among snowboarders the upper limb injuries accounted for $36.9 \%$, the truncal region for $37 \%$ and the lower limb for $26.1 \%$. The most frequent was the knee (36.8\%), the wrist (12.4) and the shoulder (11.4) injury. Skier's thumb injury was only $1.5 \%$. The most common snowboard injury was the wrist trauma $(31.6 \%)$, the head/neck/face was accounted $15.8 \%$ of all the injuries. And the ankle was injured in $10.5 \%$ of all the cases. The head/neck and the knee injury often combined with injuries of some other body part. 29 patients (13\%) had to be repatriated, the most frequent reason for the repatriation was the injury of the lower limb. Conclusions: The Hungarian sportsmen's injury patterns do not always follow data described in the international literature, but they correspond to data of countries with similar geographical situation. The injury rate of knee and of the shoulder displays same data, the injury rate of the wrist was more frequent than in the international data, and this is true both for skiers and the snowboarders. The Hungarians' injury of the truncal region (mainly the head) was more frequent, but on the other hand the general injury rate of other body parts proved to be a lower number. It seems that the frequent use of the protective equipment and the preventive measures applied by the Hungarians are mirrored in the lower injury figures.

Keywords: protective equipment, skiing, snowboarding, ski injury prevention, ambulance transport

Felkai, P., Lengyel, I., Szokoly, M., Forgó, G. [Epidemiological data of Hungarian skiers' and snowboarders' medical problems]. Orv. Hetil., 2017, 158(16), 618-624.

(Beérkezett: 2017. január 14.; elfogadva: 2017. február 25.) 
A kültéri havas sportok (elsősorban a síelés, hódeszkázás, szánkózás, korcsolyázás, sífutás) a világon az egyik legnépszerúbb rekreációs tevékenységek sorába tartoznak. Így van ez hazánkban is, noha Magyarországon nincsenek hóbiztos pályák, a sportolásra alkalmas időszak csak átlagosan 30 nap, és a hó mélysége ekkor is csak átlag 10 $\mathrm{cm}$ [1]. Mindezen hátrányok ellenére Magyarországon a becslések szerint körülbelül 550000 téli sportot üzó ember van [2]. Hóbiztos pályák csak a környező országokban találhatók, ezért a decembertől márciusig tartó síszezonban magyarok ezrei indulnak külföldre.

Mivel a szabadidősportok múvelői az év nagy részében nem a havas sportok megkövetelte mozgásminták szerint élnek, a sportolás indukálta egészségkárosodások náluk nagyobb valószínúséggel lépnek fel. A balesetek okozta kórképek, a környezet ártó hatásai (hőmérséklet, magasság, oxigénhiány), a fokozott mozgások kiváltotta betegségek, illetve a már meglevő betegségek akut fellángolásai a jellemző ártalmak. Ezért érdemes tanulmányozni a magyar amatőr téli sportolók megbetegedéseinek epidemiológiáját, annál is inkább, mert ilyen jellegü felmérés eddig csak az élsportolóknál történt. Fontos megvizsgálni, hogy honfitársaink sérülési arányai hogyan viszonyulnak a nemzetközi irodalomban közölt számokhoz.

A téli sportoknak egészen fiatal múvelői is vannak, ők leggyakrabban a szüleikkel vagy iskolás csoportokkal mennek síelni. Sajnálatos módon az iskoláskorú gyermekek balesetei a sísérülések jelentős hányadát adják [3]. Sok magyar gyermek halála (Gerlitz, 2012; Lech, 2017) indokolja a csoportokat kísérő orvosok speciális, sítábororvosi kiképzését. A képzett orvosok száma mára már elérte a 200 föt, és a téli sportra vágyó csoportok kísérésével biztonságot jelentenek az iskolás gyermekeknek [4]. Jelentőségük különösen megnőtt azóta, hogy külföldön egyre több, havas sportolásra alkalmas terület (nem is szólva a pályán kívüli síterepekrôl) üzemel a pályán rendelkezésre álló szakellátás nélkül. Sajnos, az iskolás csoportok kísérésére vonatkozó jogszabály még nem született meg, ellentétben az „extrém sportolókat” sújtó rendelettel, amely nem minősíti különösen veszélyes szabadidős tevékenységnek a téli sportokat [5]. Így az epidemiológiai adatok összehasonlítása mellett szükségessé vált a téli sportok baleseti hányadának számszerüsítése is.

\section{Módszer}

A havas sportok okozta egészségkárosodások okai között a sí- és hódeszkás sérülések, illetve a többi fajta téli sporttal összefüggő sérülések szerepelnek, amelyekről a külföldi ellátó által készített orvosi dokumentációt a biztosító segélynyújtó orvoscsoportja kapja meg. A biztosító orvosa ennek a jelentésnek, illetve egyéb biztosítói körülményeknek a figyelembevételével írásban dönt a külföldi kezelések megfelelőségéről, illetve a beteg hazaszállításáról. A hazaszállításról külön - az őrzött szállítás jellegének megfelelően - szintén dokumentáció készül.
Közleményünkben három egymást követő év téli sportszezonjában (2012. december 1-jétôl 2015. március 31-ig terjedő időszak) történt síbalesetek kerültek feldolgozásra. A vizsgálat során feldolgoztuk az egyik legnagyobb magyar utasbiztosító segélynyújtó csoportjához ez idő alatt érkezett bejelentéseket, illetve a bejelentésben szereplő betegek helyi kezelőorvosi jelentését, a segélynyújtó csoport orvosának döntését az adott egészségkárosodással kapcsolatban és a beteg további ellátását Magyarországra történt hazaérkezésükig.

A nemzetközi irodalomban szereplő epidemiológiai adatok összehasonlítása rendkívül nehéz a számtalan különböző számítási módszer miatt. Általában a sérülési arányt szokták a szerzők közölni, amelynél az adott pályán az összes sérülések számát osztják a síeléssel eltöltött napokkal $[6,7]$. Ez az érték átlagosan $0,8-9,1$ között mozog. A sérülések incidenciája egy adott időszakon belüli új sérülések számát jelenti, osztva az adott időszakon belül sportot űzők számával [8]. Közleményünkben egyik módszer sem volt alkalmazható az adatnyerés korlátozott módja miatt. Ezért a szerzők a fent említett dokumentációkból nyert adatok egyszerű statisztikai feldolgozására szorítkoztak.

\section{Eredmények}

Az áttekintett 12 hónap alatt összesen 222, havas sporttal összefüggő egészségkárosodás történt a biztosítottak között. Ebből 201 (90,5\%) sísérülés, 19 (8,6\%) hódeszkás sérülés és $2(0,9 \%)$ pályán kívüli (off-piste) síeléssel összefüggő sérülés történt; az utóbbi csoportban egy mellkas- és egy térdsérülés volt. Egyéb, havas sporttevékenységgel (korcsolya, szánkó stb.) összefüggő balesetet nem jelentettek. A pályán kívüli síelésről jelen közlemény azért nem tud részletesebb adatokkal szolgálni, mert az ilyen jellegü sporttevékenység a biztosító kötvénye értelmében kizáró ok, ezért a sérültek kárigénye nem volt fedezhető. Egy ausztriai felmérésben, amely 7325 sérülést elemzett, a síelők, a hódeszkások és a pályán kívüli síelők aránya $80 \% / 14 \% / 6 \%$ volt, tehát egy nagyobb számú áttekintésnél a hódeszkások aránya a téli sportot űzők között nagyobbnak mutatkozott [9].

A vizsgált időszakban a magyarok zömmel a környező országokban találtak a havas sportoláshoz megfelelő hóbiztos pályákat, és a sérülések is ezen országokban történtek (1. táblázat).

Hazai felmérések szerint a sportsérülések között az alsó végtag sérülései az összes sérülés 60-80\%-át adják [10]. Különösen így van ez a sísportnál, ahol a térdsérülések bizonyultak a leggyakoribbnak $(36,8 \%)$, megelőzve a csukló $(12,4 \%)$ és a vállöv $(11,4 \%)$ sérüléseit (2. táblá$z a t)$.

Anyagunkban a hódeszkás sérülések feldolgozása során a csuklósérülések bizonyultak a leggyakoribbnak $(31,6 \%)$, megelőzve a fej/nyak $(15,8 \%)$, valamint a vállöv, gerinc és boka (10,5\%) sérüléseit (3. táblázat). 
1. táblázat |A téli sportot űzők sérüléseinek helyszínei felmérésünkben

\begin{tabular}{lcc}
\hline Ország & Esetszám & $\%$ \\
\hline Ausztria & 176 & 79,2 \\
Franciaország & 34 & 15,3 \\
Olaszország & 8 & 3,6 \\
Szlovákia & 3 & 1,4 \\
Svájc & 1 & 0,5 \\
\hline Összesen & 222 & 100 \\
\hline
\end{tabular}

2. táblázat |A sísérülések leggyakoribb előfordulási helyei

\begin{tabular}{|c|c|c|c|c|}
\hline Testtájék & Testrész & Esetszám & $\begin{array}{c}\text { Összes } \\
\text { sérülés (\%) }\end{array}$ & $\begin{array}{c}\text { Testtájéksérülés } \\
(\%)\end{array}$ \\
\hline \multirow{5}{*}{$\begin{array}{l}\text { Felső } \\
\text { végtag }\end{array}$} & Hüvelykujj & 3 & 1,5 & \multirow[t]{5}{*}{19,9} \\
\hline & Csukló & 25 & 12,4 & \\
\hline & Alkar & 4 & 2 & \\
\hline & Könyök & 2 & 1 & \\
\hline & Felkar & 6 & 3 & \\
\hline \multirow[t]{4}{*}{ Törzs } & Vállöv & 23 & 11,4 & \multirow[t]{4}{*}{24,4} \\
\hline & Gerinc & 4 & 2 & \\
\hline & $\mathrm{Fej} / \mathrm{arc} /$ nyak & 16 & 8 & \\
\hline & Mellkas & 6 & 3 & \\
\hline \multirow{5}{*}{$\begin{array}{l}\text { Alsó } \\
\text { végtag }\end{array}$} & Csípő & 7 & 3,5 & \multirow[t]{5}{*}{55,8} \\
\hline & Comb & 7 & 3,5 & \\
\hline & Térd & 74 & 36,8 & \\
\hline & Alszár & 20 & 10 & \\
\hline & Boka & 4 & 2 & \\
\hline
\end{tabular}

3. táblázat |A snowboardos sérülések leggyakoribb előfordulási helyei

\begin{tabular}{llccc}
\hline Testtájék & Testrész & Esetszám & $\begin{array}{c}\text { Összes } \\
\text { sérülés }(\%)\end{array}$ & $\begin{array}{c}\text { Testtájéksérülés } \\
(\%)\end{array}$ \\
\hline Felső & Hüvelykujj & 1 & 5,3 & 36,9 \\
végtag & Csukló & 6 & 31,6 & \\
& Alkar & 0 & 0 & \\
& Könyök & 0 & 0 & \\
& Felkar & 0 & 0 & \\
\hline Törzs & Vállöv & 2 & 10,5 & \\
& Gerinc & 2 & 10,5 & \\
& Fej/arc/nyak & 3 & 15,8 & \\
& Mellkas & 2 & 10,5 & \\
\hline Alsó & Csípő & 0 & 0 & \\
végtag & Comb & 0 & 0 & \\
& Térd & 1 & 5,3 & \\
& Alszár & 1 & 5,3 & \\
& Boka & 2 & 10,5 & \\
\hline
\end{tabular}

4. táblázat | Egyszerú és többszörös sérülések testrészenként

\begin{tabular}{lrcc}
\hline Testrész & Izolált & Multiplex & Összesen \\
\hline Hüvelykujj & 4 & 0 & 4 \\
Csukló & 26 & 5 & 31 \\
Alkar & 3 & 1 & 4 \\
Könyök & 2 & 0 & 2 \\
Felkar & 5 & 1 & 6 \\
Váll & 22 & 3 & 25 \\
Gerinc & 4 & 2 & 6 \\
Fej/arc & 12 & 7 & 19 \\
Mellkas & 7 & 2 & 9 \\
Csípő & 6 & 1 & 7 \\
Comb & 5 & 2 & 7 \\
Térd & 68 & 8 & 76 \\
Alszár & 20 & 1 & 21 \\
Boka & 5 & 0 & 5 \\
\hline Összesen & 189 & 33 & 222 \\
\hline & & & \\
\hline & & 21 & 6 \\
\hline
\end{tabular}

5. táblázat |A repatriációs módok a sérült testtájak tükrében

\begin{tabular}{lcccc}
\hline Sérülés helye & \multicolumn{3}{c}{ Repatriációs mód } & Összesen \\
\cline { 2 - 4 } & Mentőautó & Járatgép & Személyautó & \\
\hline Váll & 1 & 0 & 1 & 2 \\
Gerinc & 2 & 0 & 0 & 2 \\
Fej/arc & 1 & 0 & 0 & 1 \\
Csípő & 2 & 0 & 0 & 2 \\
Felső végtag & 1 & 1 & 0 & 2 \\
Térd & $\mathbf{5}$ & 0 & 3 & 8 \\
Alsó végtag & $\mathbf{8}$ & 0 & 1 & 9 \\
Boka & 1 & 0 & 1 & 2 \\
Mellkas & 0 & 0 & 1 & 1 \\
\hline Összesen & 21 & 1 & 7 & 29 \\
\hline
\end{tabular}

Megvizsgáltuk, hogy a különböző testrészek sérülése mennyiben kombinálódik más testrész sérülésével (4. táblázat).

A 222 havas sportsérült közül 29 beteget (az összes beteg 13\%-át) kellett hazaszállítani. A hazaszállítás fó oka az alsó végtag sérülése volt, ami miatt a beteg nem tudott önállóan közlekedni (5. táblázat). A téli sportolók repatriációjának (amely orvosi tevékenység, és nemcsak a hazaszállítást jelenti, hanem a beteg szállítható állapotba hozását, felkészítését a szállításra) jellegzetességeit egy külön közleményben kívánjuk ismertetni.

Közismert, hogy a téli sportolással összefüggő sérülések egyharmada az első nap, az összes sérülések $57 \%$-a az első két nap alatt fordul elő [11]. Sajnálatos módon ezt az adatot nem volt mód kinyerni az elemzés során, mert ez a tény közömbös volt a kárelbírálás során, ezért nem is kellett a biztosítottnak ez irányban nyilatkoznia. 
Ugyancsak nem tudtuk felmérni a hazatérés utáni további kórházi kezelésre szorulók számát, mert a segélynyújtó központ orvosi protokollja minden beteg kórházi átadását követeli meg.

\section{Megbeszélés}

\section{A havas sportok baleseteinek predilekciós tényezöi}

$\mathrm{Az}$ adatok elemzése lehetőséget adott több, a magyar szabadidő-sportolók téli sportolásával kapcsolatos következtetés levonására. A vizsgált időszakban a legnépszerübbek az ausztriai sírégiók voltak nyilvánvaló közelségük miatt. Itt történt a legtöbb sérülés is. A közeli elérés előnyét nem írja felül az a tény, hogy az ausztriai pályák legtöbbjén nincs orvosi-ápolói segitség, vagyis a kórházi ellátás előtt az önkéntes segélynyújtó a sípályán legfeljebb a sérült végtag rögzítését végzi el. Súlyosnak imponáló baleseteknél azonnal a mentőhelikoptert hívják a pályafenntartók, de valószínúleg financiális viszonzási érdekből a „maszek” helikopteres mentés - rendszerint a hivatásos mentőhelikopter-hálózat megkerülésével - jóval gyakoribb az indokoltnál.

Az ausztriai hóbiztos pályák közelsége persze relatív: mindegyikük csak többórás autóvezetéssel érhető el, tehát a síelő már eleve fáradtan érkezik a céljához. A szakirodalomban ellentmondó adatok találhatók a fáradtságnak és az előzetes bemelegítés hiányának a sérülések gyakoriságát fokozó voltára [12-14]. Saját tapasztalataink szerint - mint általában az utazók viselkedési kockázatainál is - inkább a sportoló egészségi állapotából eredő kockázatok, illetve a veszélyeztető attitúd (kockázatvállaló magatartás, alkoholizálás, a sportolás akár kisebb sérüléssel járó eróltetése és a sportolás közbeni telefonálás, zenehallgatás) a sérülések előszobája.

A havas sportok kiemelkedő veszélyességéról is megoszlanak a vélemények. Egyes szerzők relativizálják a veszélyt, arra hivatkozva, hogy nincs a sportokat e téren összehasonlító adat [15], magunk a különböző - és öszszehasonlító! - irodalmi közlemények alapján a téli sportok veszélyességét relatíve magasnak tartjuk [16]. Az 1000 sportórára vetített sérülési arányt a síelésnél 3,7-tôl 8-ig, sőt gyermekkorúaknál 9,1-ig terjedő számban találtak $[6,13,17]$. A hódeszkás magyar élsportolók sérülési arányát 4-6/1000 sportórának találták [18]. Összehasonlításképpen például az ökölvívóknál 2 , a rögbiseknél pedig 7-18 fó/1000 sportóra volt a sérülések száma $[19,20]$. Magyar adatok szerint a leginkább sérülésveszélyes szabadidős sportágaknak a labdarúgás után a síelést és a hódeszkázást találták a szerzők, míg a leggyakrabban sérülő testrész a térdízület, a vállízület és a gerinc volt. A szerzők a magyar hódeszkás versenyzők sérülékenységét kiemelkedően magasnak értékelték [21]. A magasabb sérülési ráta a nagyobb kockázatvállalásra, a gyengébb felkészültségre és kondicionális állapotra, valamint a védőfelszerelések ritkább használatára vezethető vissza [18]. Nem tekinthető véletlennek, hogy az olimpiai sportágak közül is a téli sportok [22], azon belül is a hódeszka a legnagyobb sérülési aránnyal járó sportág, megelőzve a sísportágakat [23].

\section{A magyar sportolók sérülési arányai a nemzetközi irodalmi adatok tükrében}

A nemzetközi felmérések alapján a hódeszkás sérülések legnagyobb hányadát a csukló sérülése adja. Anyagunkban ez $31,6 \%$ volt, míg a szakirodalom $11,27,6$ és 62\%-ot említ [18, 24, 25]. A síelők csuklósérülése a magyar sportolóknál 12,4\% volt, míg a külföldi beszámolók 2,8 és 5,5\%-ról számolnak be $[24,26]$.

A magyar síelőknél a vállöv sérülése volt a második leggyakoribb sérülésforma (11,4\%). Nemzetközi adatok szerint ez a sérülésfajta $8,1 \%$, illetve $18 \%$ volt $[9,26]$.

A síelők felsővégtag-sérüléseinek felmérésénél 21,9\%ot találtunk, míg mások 20-35\%-ot, sőt 62\%-ot számoltak [27, 28]. Hasonló eredményt, 20\%-os sérülési arányt találtak hollandiai kutatók, ahol - Magyarországhoz hasonlóan - a sportolók külföldre járnak síelni [29]. A magyar hódeszkázó sérülteknél a felső végtagi sérülések voltak a gyakoribbak: 36,9\%. Más magyar adatok a felső végtagnál 30\%-os sérülési arányt találtak [18]. A külföldi szakirodalomban a hódeszkások felső végtagi sérülése $20-50 \%$ volt [27].

A síelők törzssérüléseinek aránya anyagunkban 24,4\% volt. Meglepő, hogy a hódeszkázók között is a törzs sérülései (ezen belül is a fejsérülések) szerepeltek leggyakrabban a testtájak sérülései között, 37\%-os aránnyal. A fej, gerinc és hastáj más szerzőnél is magas értéket (>20\%) mutatott [30]. Fóleg a gerinc 21\%-os érintettsége hívja fel a figyelmet arra, hogy a gerincvédóket nem kellő mértékben használják, még az élsportolók sem [18].

Fejsérülések anyagunkban 8 (sí) és 15,8\%-ban (hódeszka) fordultak elő. A nemzetközi irodalomban a fejarc sérülések arányát a síelőknél 8-47,1\%-nak, a hódeszkásoknál 27,3\%-nak találták [30,31]. A fejsérülések elkerülésére tették kötelezővé a sisak használatát a gyermekek részére Ausztriában és Olaszországban, és minden sportolónak az Amerikai Egyesült Államok több államában és Kanadában. Noha eleinte a fejsérülések 60\%-os csökkenését figyelték meg, mára ez a csökkenés megállt, sőt újra növekszik [32]. Ugyancsak növekvőben van a mellkasi és gerincsérülések aránya, mivel a síelési technika (carving sí) változása lehetővé teszi a nagyobb sebességú lesiklást, a gyors fordulókat. Ugyancsak elgondolkoztató adat az, hogy az agyrázkódást szenvedett fiatalkorú téli sportolóknál nem volt szignifikáns különbség a sisakot viselők, illetve nem viselők között [33]. A mellkasi sérülések a síelőknél anyagunkban 3\%-kal, míg egy felmérésben 40,2\%-kal szerepeltek [31]. A hódeszkásoknál a mellkasi sérülések 10,5\%-os arányát figyeltük meg, a nemzetközi irodalomban erre vonatkozó számot nem találtunk. Általában feltünő volt, hogy a magyar hódesz- 
kásoknál a törzs sérülései milyen magas számban (10,5\%) szerepeltek: az összes törzstáji sérülés több mint egyharmadát tették ki.

A szakirodalomban a többszörös sérülések arányát is növekvőnek találták [31]. A többszörös sérülések fóleg a térd-, a csukló-, a fej- és az arcsérülések között fordultak elő nagyobb számban. A térdsérülést a felkar és váll, a csuklósérülést a vállöv (fóleg a clavicula), míg a fejsérülést a törzstájak sérülései kísérték gyakrabban.

A síelőknél az alsó végtag sérülései gyakoribbak, ez a külföldi adatok szerint 22-38\%, illetve 51,3\% [23, 28, $30]$. Anyagunkban az alsó végtag sérülései $55,8 \%$-ban szerepeltek, egy 1994-es felmérésben ez az arány még jóval magasabb, 79,3\% volt [34]. Holland felmérések szerint az alsó végtagi sérülések aránya 54\% volt [29].

A síelők jellegzetes sérüléstípusának a térd sérülését, ezen belül is az első keresztszalag sérülését tartják. Anyagunkban a térdsérülések 36,8\%-ban fordultak elö, magyar adatok $57,3 \%$, a nemzetközi felmérések pedig ezt az arányt 14,4-41\%-ig terjedő tartományba helyezik, a gyermek sportolóknál ez az arány $47,7 \%$ volt $[9,17,26$, 34]. Dániában, ahol a sportolók szintén külföldre járnak síelni, a térdsérülések aránya $40 \%$ volt.

Magyar adatok [18] a hódeszkás sérülteknél az alsó végtag 47\%-os sérülési arányát találták, bár a szerzők javarészt profi sportolókról készítettek felmérést. Az általunk észlelt relatíve alacsony, 26,0\% körüli hódeszkás alsó végtagi sérülési ráta valószínúleg a védőeszközök fokozott használatának és a gyors belépős kötéseknek köszönhetően csökkent le 50\%-ról [35].

A hódeszkások vezető sérülése az alsó végtagon a boka sérülése volt $(10,5 \%)$, ezt az arányt a nemzetközi szakirodalom 15,3-26\%-ra teszi [36, 37]. Ámbár a szignifikanciavizsgálatok a hódeszkás bokasérüléseket növekvőnek találták, a régebbi és az egy évtizeddel későbbi adatok csökkenő tendenciát mutatnak [24]. Ez a sérülésfajta („hódeszkás boka”) valószínúleg az új tervezésú kötéseknek és a merev csizmák elterjedésének (amelyek a puha „freestyle” hódeszkáscipők mellett az „alpin” stílusirányzatnak megfelelően kaphatók) köszönhető.

Anyagunkban halálos baleset nem fordult elő. A külföldi közlemények szerint a halálozási arány az összes sérültek között 11\%, ami véleményünk szerint türhetetlenül magas, és oka sokszor a sérültek kimentésének hosszadalmas volta. Az időfaktor csökkentése miatt kezdtük 2006-ban a magyar orvosok sítábororvosi képzését [38]. Sajnálatos módon - mint azt Schumacher balesete is mutatja - a sisak nem véd meg attól, hogy eséskor az agyállomány nagy sebességgel ne ütődjön a koponyacsonthoz, agyrázkódást, súlyosabb esetben koponyaưri vérzést okozva. Ettől függetlenül több szerző a sisak védelmét nagyra értékeli [39].

\section{A havas sportok sérültjeinek repatriációja}

A hazahozatal leggyakoribb indikációja a sportolás folytatásának lehetetlensége és a hagyományos úton való visszautazás akadályozottsága volt, az alsó végtag sérülése miatt. A repatriáció legfőbb módja a vizsgált időszakban a mentőgépkocsi volt, mert az interhospitalis szállítási idő - az Európán belüli relatíve kis távolságok miatt - szinte egyenlő volt a menetrend szerinti repülőgépjáratot igénybe vevő repatriációs módszerrel.

\section{Következtetések}

Általánosan elfogadott a havas sportok sérüléseinek öszszegző szakirodalmában [40] az, hogy a sísérülések leggyakoribb helye a térd (43\%), a vállöv (12\%) és a hüvelykujj $(8 \%)$. Ezek az értékek a szerzők által vizsgált anyagban a következőképpen alakultak: térd 36,8\%, csukló $12,4 \%$, vállöv $11,4 \%$. A hüvelykujj sérülése volt a legkisebb arányú $(1,5)$ az összes sérülés között.

Hasonló összehasonlításban a szakirodalom a hódeszkás sérüléseknél a csukló (18\%), a vállöv (14\%), a boka és a térd egyaránt 13\%-os részesedését írja le. Jelen közleményben a szerzők szintén a csukló sérüléseit találták a leggyakoribb sérülésnek $(31,6 \%)$, azonban a második helyen a fej/arc/nyak sérülései (15,8\%), majd harmadikként a vállöv, a gerinc, a mellkas és a boka sérülései szerepeltek 10,5\%-10,5\%-kal.

A csukló sérülési aránya nemcsak a hódeszkás sportolóknál volt kiemelkedően magas, hanem a síelőknél is. Valószínúleg a jobb csizmáknak köszönhetően az 1960as években észlelt és leírt „síelőboka”-sérülések átadták a helyüket a „hódeszkás boká”-nak. A jó felszereléseknek köszönhetően a bokasérülések ebben a sportágban is csökkentek, de a sérülések itt is „felcsúsztak” az alsó lábszár és a térd vonalába. A vállöv sérülése (különösen a clavicula törése) mindkét sportfajtában magasnak bizonyult.

A törzs sérülései kiemelkedően magasak voltak a magyar hódeszkásoknál, míg a síelőknél továbbra is az alsó végtag sérülései adták a sérülések több mint felét.

Az összehasonlító adatokból nyert információ azt mutatja, hogy a magyar havas sportok müvelőinek sérülésmintái csak részben követik a nemzetközi szakirodalomban leírtakat. (Igaz, ez utóbbiak javarészt olyan országokban készültek, ahol a havas sportokra alkalmas terepek vannak.) E tekintetben a Magyarországéhoz hasonló geográfiai adottságú országokban a sérülési arányok az általunk talált arányok körül mozognak [41]. Az összképet tekintve azonban meg kell állapítanunk, hogy a magyar havas sportok kedvelőinek sérülési arányszámai alacsonyabbak a nemzetközi adatokban közölteknél. Úgy tűnik, hogy aki a sípályára utazás költségeit megengedheti magának, annak a sport- és védőfelszerelése is jobb minőségü, másrészt a hosszú út fáradalmait vállalók többsége valóban elkötelezett és a biztonságos technikát elsajátított kedvtelési sportoló. Így tehát a felszerelések jó minősége, a védőfelszerelések kiterjedt használata, a pályán tanúsított veszélykerülő magatartás és a jó technikai tudás egyaránt eredményezi a havas sportbalesetek 
csökkenését, de ezt a megállapítást szinte mindegyik közlemény közismert tényként hangsúlyozza.

A havas sportok veszélyeire való figyelemfelhívásnak helyet kellene kapnia az utazás előtti tanácsadás témái között is: ezt az oltóközpontok - amelyeknek feladata a vakcinálás mellett az utazási tanácsadás is - nem teszik meg. A gyermekek fokozott sérülésveszélye miatt indokolt lenne a jogszabály ereje által a kiképzett tábororvosok gyermekcsoportok mellé rendelése, a tömegsportért felelős politikusok ilyen irányú döntésének sürgetése pedig a sérüléseket kezelő és azok okait feltáró orvosok feladata.

Anyagi támogatás: A közlemény megírása, illetve a kapcsolódó kutatómunka anyagi támogatásban nem részesült.

Szerzői munkamegosztás: F. P.: Vizsgálat lefolytatása, statisztikai elemzések, a kézirat megszövegezése. L. I.: A sportsérülések pszichológiai hátterének áttekintése. Sz. M.: A sérülések elemzésének traumatológiai szakmai ellenőrzése. F. G.: Szakirodalom áttekintése. A cikk végleges változatát valamennyi szerző elolvasta és jóváhagyta.

Érdekeltségek: A szerzőknek nincsenek érdekeltségeik.

\section{Köszönetnyilvánítás}

A szerzők köszönetet mondanak az SOS Hungary munkatársainak, elsősorban Maczali Veronikának és Makai Juditnak az anyag statisztikai feldolgozásában való segítségükért, valamint Olexó Zsuzsának és $d r$. Hittner Györgynek, a Sportorvosi Szemle, illetve a Magyar Reumatológia főszerkesztőjének az irodalomkutatásban nyújtott segítségért.

\section{Irodalom}

[1] Hirsch, T.: Synoptic-climatological investigation of weather systems causing heavy precipitation in winter in Hungary. Időjárás, 2000, 104(3), 173-196.

[2] Vanat, L.: 2016 International report on snow \& mountain tourism - Overview of the key industry figures for ski resorts. Geneva, 2016. ISBN: 978-2-9701028-1-6

[3] Greier, K.: Skilaufverletzungen im Schulsport und Möglichkeiten der Prävention. Sportverletz Sportschaden, 2011, 25(4), 216221.

[4] Felkai, P., Clements, C. W.: New methods for practice oriented post-graduate medical education: training of a ski-camp doctor in Hungary. Wilderness Environ. Med., 2008, 19(2), 134-139.

[5] Government Decree No 217/1997 (XII.1) on implementation of the Act LXXXIII of 1997 on the benefits of compulsory health insurance, Section 5B. [217/1997. (XII. 1.) korm. rendelet a kötelező egészségbiztosítás ellátásairól szóló 1997. évi LXXXIII. törvény végrehajtásáról, $5 \mathrm{~B}$ \$.] [Hungarian]

[6] Warme, W. J., Feagin, J. A. Jr., King, P.: Ski injury statistics, 1982 to 1993, Jackson Hole Ski Resort. Am. J. Sports Med., 1995, 23(5), 597-600.

[7] Burtscher, M., Gatterer, H., Flatz, M., et al.: Effects of modern ski equipment on the overall injury rate and the pattern of injury location in Alpine skiing. Clin. J. Sport Med., 2008, 18(4), 355357.
[8] Phillips, H. L.: Sports injury incidence. Br. J. Sports Med., 2000, 34(2), 133-136.

[9] Ruedl, G., Philippe, M., Sommersacher, R., et al.: Aktuelles Unfallgeschehen auf österreichischen Skipisten. Sportverletz Sportschaden, 2014, 28(4), 183-187.

[10] Berkes, I.: Sport surgery. In: Jákó, P., Martos, É., Pucsok, J. (eds.): Principles of sport medicine. [Sportsebészet. In: Jákó, P., Martos, É., Pucsok, J. (szerk.): A sportorvoslás alapjai.] Budapest, Print City Nyomda, 1998, 117-167. [Hungarian]

[11] Ruedl, G., Helle, K., Tecklenburg, K., et al.: Einfluss von subjektiver Ermüdung auf vordere Kreuzbandverletzungen beim alpinen Skifahren: Ein Geschlechtervergleich. Sportverletz Sportschaden, 2015, 29(4), 226-230.

[12] Hunter, R. E.: Skiing injuries. Am. J. Sports Med., 1999, 27(3), 381-389.

[13] Koehle, M. S., Lloyd-Smith, R., Taunton, J. E.: Alpine ski injuries and their prevention. Sports Med., 2002, 32(12), 785-793.

[14] Hagel, B.: Skiing and snowboarding injuries. Med. Sport Sci., 2005, 48, 74-119.

[15] Johnson, R. J., Ettlinger, C. F., Shealy, J. E.: Myths concerning alpine skiing injuries. Sports Health, 2009, 1(6), 486-492.

[16] Felkai, P.: Chasing of phantoms: recent problems of "extreme sportsmen's" health care, with the approach of a travel medicine specialist. [Fantomok kergetése: az „extrém” sportolók egészségügyi ellátásának aktuális kérdései utazásorvostani megközelítéssel.] IME, 2010, 9(2), 17-21. [Hungarian]

[17] Meyers, M. C., Laurent, C. M., Higgins, R. W., et al.: Downhill ski injuries in children and adolescents. Sports Med., 2007, 37(6), $485-499$

[18] Tállay, A., Halasi, T., Berkes, I.: Presentation of the snowboard injuries. [A snowboard-sérülések bemutatása.] Sportorvosi Szemle, 1998, 39(4), 237-245. [Hungarian]

[19] Zazryn, T., Cameron, P., McCrory, P.: A prospective cohort study of injury in amateur and professional boxing. Br. J. Sports Med., 2006, 40(8), 670-674.

[20] McIntosh, A. S.: Rugby injuries. Med. Sport Sci., 2005, 49, 120139.

[21] Hidas, P., Szakács, N.: Sport injuries of the patients at hospital for sports. [Sportsérülések előfordulása a sportkórházban.] Sportorvosi Szemle, 2011, 52(4), 113-124. [Hungarian]

[22] Milne, C., Shaw, M., Steinweg J.: Medical issues relating to the Sydney Olympic Games. Sports Med., 1999, 28(4), 287-298.

[23] Engebretsen, L., Steffen, K., Alonso, J. M., et al.: Sports injuries and illnesses during the Winter Olympic Games 2010. Br. J. Sports Med., 2010, 44(11), 772-780.

[24] Kim, S., Endres, N. K, Johnson, R. J., et al.: Snowboarding injuries: trends over time and comparisons with alpine skiing injuries. Am. J. Sports Med., 2012, 40(4), 770-776.

[25] Matsumoto, K., Miyamoto, K., Sumi, H., et al.: Upper extremity injuries in snowboarding and skiing: a comparative study. Clin. J. Sport Med., 2002, 12(6), 354-359.

[26] Khalilifar, A. H., Kazemi, M. H., Hamedanchim, A., et al.: Skiing injuries at the Dizin Ski Resort. Trauma Mon., 2012, 17(1), 259-261.

[27] Kocher, M. S., Dupré, M. M., Feagin, J. A. Jr.: Shoulder injuries from alpine skiing and snowboarding. Aetiology, treatment and prevention. Sports Med., 1998, 25(3), 201-211.

[28] Aslam, N., Thomas, P.: Snowdome, skiers and boarders: accident and emergency experience. Int. J. Clin. Pract., 2004, 58(2), 122-124.

[29] Bouter, L. M., Knipschild, P. G., Volovics, A.: Binding function in relation to injury risk in downhill skiing. Am. J. Sports Med., 1989, 17(2), 226-233.

[30] Wasden, C. C., McIntosh, S. E., Keith, D. S., et al.: An analysis of skiing and snowboarding injuries on Utah slopes. J. Trauma, 2009, 67(5), 1022-1026. 
[31] Weber, C. D., Horst, K., Lefering, R., et al.: Major trauma in winter sports: an international trauma database analysis. Eur. J. Trauma Emerg. Surg., 2016, 42(6), 741-747.

[32] Sulbeim, S., Ekeland, A., Holme, I., et al.: Helmet use and risk of head injuries in alpine skiers and snowboarders: changes after an interval of one decade. Br. J. Sports Med., 2017, 51(1), 44-50.

[33] Bergmann, K. R., Flood, A., Kreykes, N. S., et al.: Concussion among youth skiers and snowboarders: A Review of the National Trauma Data Bank From 2009 to 2010. Pediatr. Emerg. Care, 2016, 32(1), 9-13.

[34] Erdélyi, G.: Injury forms of the alpine skiing and their prevention. [Az alpesi sízés mozgásszervi sérülései és azok megelőzési lehetőségei.] Magyar Reumatológia, 1994, 35(2), 99-105. [Hungarian]

[35] Müller, R., Brügger, O., Mathys, R., et al.: Snowboarding accidents. [Snowboarding unfälle.] Sportverletz Sportschaden, 2000, 14(4), 121-127. [German]

[36] Kirkpatrick, D. P., Hunter, R. E., Janes, P. C., et al.: The snowboarder's foot and ankle. Am. J. Sports Med., 1998, 26(2), 271277
[37] Bladin C., McCrory P.: Snowboarding injuries. An overview. Sports Med. 1995, 19(5), 358-364.

[38] Felkai, P.: The ski camp doctor's role in the prevention of winter sport accidents. [A sítábororvos-képzés szerepe a téli sportbalesetek prevenciójában.] Orv. Hetil., 2007, 148(34), 16151619. [Hungarian]

[39] Cusimano, M. D., Kwok, J.: The effectiveness of helmet wear in skiers and snowboarders: a systematic review. Br. J. Sports Med., 2010, 44(11), 781-786.

[40] Coury, T., Napoli, A. M., Wilson, M., et al.: Injury patterns in recreational alpine skiing and snowboarding at a mountainside clinic. Wilderness Environ. Med., 2013, 24(4), 417-421.

[41] Moller-Madsen, B., Jakobsen, B. W., Villadsen, I.: Skiing injuries: a study from a Danish community. Br. J. Sports Med., 1990, $24(2), 123-124$.

(Felkai Péter dr., e-mail: peter.felkai@soshungary.hu)

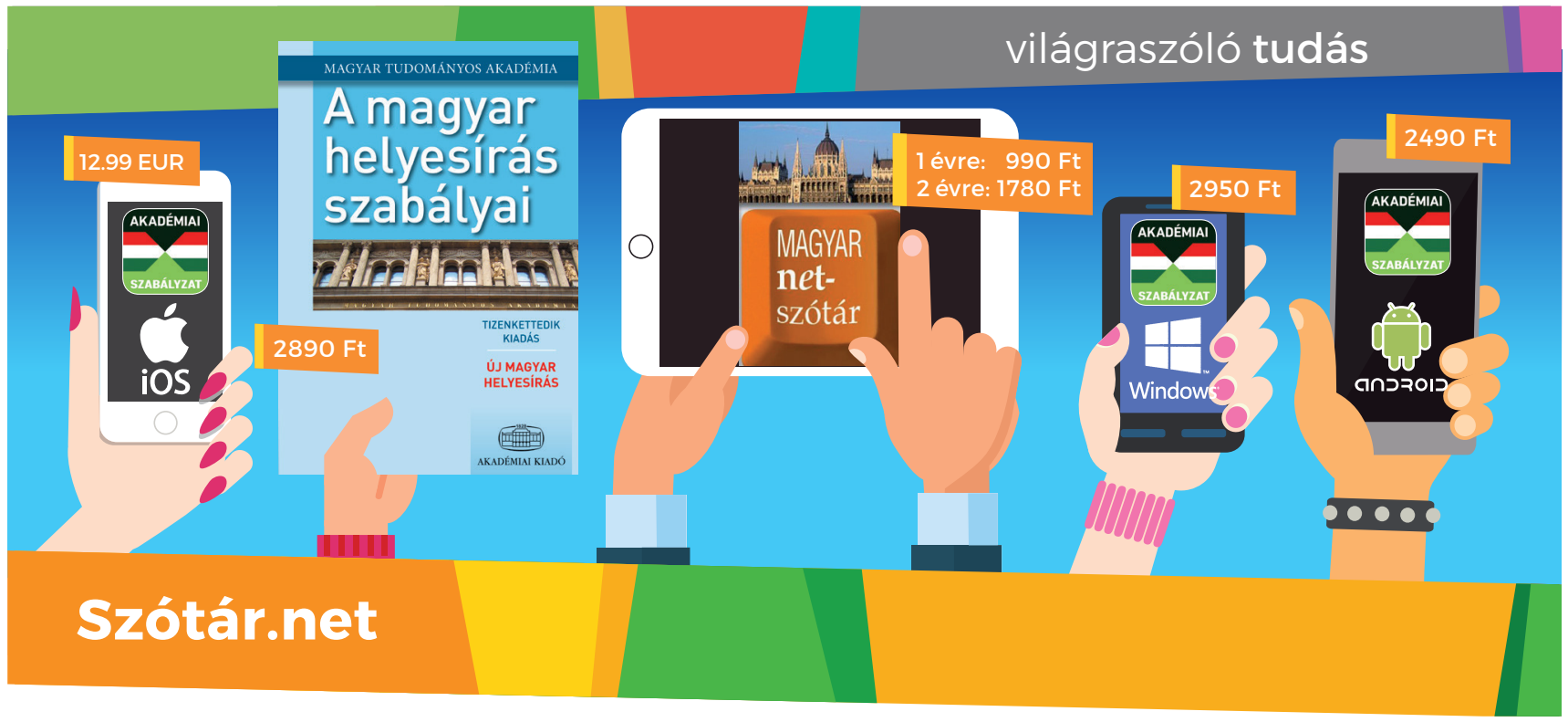

\section{A magyar helyesírás szabályai 12. kiadás Mindig a keze ügyében!}

- a Magyar Tudományos Akadémia szabályzata

- 300 szabálypont példákkal

- szabályzat és szótár egyben
- a 11. és a 12. kiadás közti különbségek felsorolása, példákkal

- tárgymutató

Keresse a könyvet a www.akademiai.hu oldalon, vagy válassza az online változatot és a mobilalkalmazást a www.szotar.net-en!
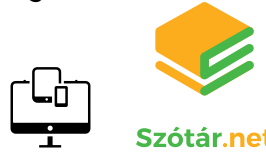

Szótár.net AKADÉMIAI KIADÓ 